\title{
Model penguatan loyalitas mahasiswa melalui kualitas pelayanan bimbingan akademik dan kepuasan mahasiswa
}

\author{
Salamatun Asakdiyah ${ }^{1^{*}}$, Deny Ismanto ${ }^{1}$ \\ ${ }^{1}$ Universitas Ahmad Dahlan, Indonesia
}

\begin{tabular}{l} 
Article Info \\
\hline Article history: \\
Received Mar $11^{\text {th }}, 2021$ \\
Revised Apr $05^{\text {th }}, 2021$ \\
Accepted May $07^{\text {th }}, 2021$ \\
\hline
\end{tabular}

\section{Keyword:}

Kualitas layanan

Student satisfaction

Student loyalty

\begin{abstract}
This study aims to examine the effect of academic guidance service quality, student satisfaction and the interaction between service quality and student satisfaction in strengthening student loyalty. The sample was determined by convenience sampling and purposive sampling methods. The data was collected by quisioner providing a list of questions to the respondents which contained the quality of service, student satisfaction and student loyalty. The analytical tool used is Moderator Regression Analysis. Meanwhile, to test the hypothesis put forward, the t test and F test are used.. Meanwhile, to find out how much the variables of academic guidance service quality, student satisfaction and the interaction between service quality and student satisfaction were able to explain the student loyalty variables used the coefficient of determination analysis. The results of the partial regression coefficient test with the $t$ test explain that the quality of academic guidance services, student satisfaction and the interaction between service quality and academic guidance with student satisfaction affect student loyalty. Meanwhile, the regression coefficient test simultaneously results that the quality of academic guidance services, student satisfaction and the interaction between the quality of academic guidance services and student satisfaction have an effect on student loyalty.
\end{abstract}

C 2021 The Authors. Published by IICET.

This is an open access article under the CC BY-NC-SA license

(https://creativecommons.org/licenses/by-nc-sa/4.0)

\section{Corresponding Author:}

Salamatun Asakdiyah,

Universitas Ahmad Dahlan

Email: salamatun_2009@yahoo.com

\section{Pendahuluan}

Dengan diberlakukannya masyarakat ekonomi ASEAN pada tahun 2015, maka salah satu lembaga yang merasakan dampak perkembangan ekonomi global adalah Perguruan Tinggi. Nasir (2016) mengemukakan bahwa peningkatan daya saing perguruan tinggi perlu dilakukan dengan reformasi pendidikan tinggi, sehingga akan meningkatkan kualitas sumber daya pendidikan di Indonesia baik mahasiswa, lulusannya dan pendidikannya.Berdasarkan persepsi ini, maka dapat diketahui terpenuhi tidaknya harapan mahasiswa. Kepuasan terjadi ketika harapan-harapannya terpenuhi, dan sebaliknya ketidakpuasan akan terjadi ketika harapan-harapannya tidak terpenuhi (Brown dan Swartz, 1989).

Salah satu bentuk pelayanan fakultas di bidang akademik adalah pelayanan yang berkaitan dengan pelaksanaan perkuliahan. Bimbingan akademik merupakan proses belajar-mengajar dalam bentuk konsultasi yang dilakukan oleh mahasiswa dengan Dosen Pembimbingnya dalam rangka untuk menyelesaikan perkuliahan. Bimbingan akademik dapat dilakukan minimal 3 kali dalam satu semester baik sebelum mengambil matakuliah, pelaksanaan ujian tengah semester maupun ujian akhir semester. Hasil studi Wei dan 
Ramalu (2011) membuktikan bahwa kualitas pelayanan berpengaruh terhadap kepuasan mahasiswa. Selain itu Kaura dan Datta(2012) membuktikan pengaruh kualitas pelayanan yang mencakup people, process dan physical evidence terhadap pelanggan. Hasil studi ini didukung oleh Kaura(2013) yang menunjukkan bahwa kualitas pelayanan menjadi anteseden kepuasan pelanggan. Demikian juga hasil studi Kaura et. al.(2015) membuktikan bahwa kualitas pelayanan berpengaruh terhadap kepuasan pelanggan dan loyalitas pelanggan. Hasil studi Asakdiyah (2018) menunjukkan bahwa kualitas pelayanan berpengaruh terhadap kepuasan mahasiswa dan loyalitas mahasiswa yg diukur melalui komunikasi word of mouth mahasiswa.

Tjiptono (2019) mendefinisikan kualitas pelayanan merupakan tingkat keunggulan yang diharapkan dan pengendalian atas tingkat keunggulan tersebut untuk memenuhi keinginan pelanggan. Tjiptono(2019) mendefinisikan kepuasan pelanggan sebagai suatu sikap yg diputuskan berdasarkan pengalaman yang didapatkan.Apabila layanan yang diharapkan pelanggan lebih besar dari layanan yang nyata-nyata diterima pelanggan maka dapat dikatakan bahwa layanan tidak bermutu. Sedangkan jika layanan yang diharapkan pelanggan lebih rendah dari layanan yang nyata-nyata diterima pelanggan maka dapat dikatakan bahwa layanan bermutu, dan apabila layanan yang diterima sama dengan yang diharapkan maka layanan tersebut dikatakan memuaskan (Fitzsimmons \& Fitzsimmons, 1994). Dengan demikian Service Quality merupakan suatu cara untuk mengetahui seberapa jauh perbedaan antara kenyataan dan harapan pelanggan atas layanan yang diterima (Parasuraman, Zeithaml dan Berry, 1988). Sedangkan Cronin dan Taylor (1992) mendefinisikan kualitas pelayanan sebagai persepsi pelanggan terhadap kualias sebagai kinerja. Cronin dan Taylor (1992) membuktikan bahwa kualitas pelayanan ditentukan oleh kinerja jasa tersebut.

Analisis SERVQUAL (Service Quality) merupakan analisis untuk mengukur kualitas jasa, yaitu : Tangibles, Reliability, Responsiveness, Assurance dan Empathy. Meskipun analisis SERVQUAL secara empirik telah diuji pada jasa bank, jasa telepon, dan sebagainya, akan tetapi analisis SERVQUAL tidak selalu berhasil diterapkan pada jasa pendidikan. Oleh karena itu, dalam penelitian yang dilakukan oleh Joseph, Yakhou dan Stone (2005) diajukan beberapa faktor kualitas jasa pendidikan. Ketiga peneliti ini mengukur kualitas jasa pendidikan dengan menggunakan delapan faktor kualitas jasa pendidikan yang terdiri dari 29 item. Kedelapan faktor kualitas jasa pendidikan tersebut mencakup : University Staff, Recreational Activities, Facilities, Campus Environment, Reputation, Cost, Advice dan Schedule. Hasil studi ketiga peneliti ini menunjukkan bahwa kedelapan faktor ini dapat mengarahkan dan memberikan keyakinan terhadap kualitas jasa pendidikan berdasarkan perspektif mahasiswa. Jusoh et.al. (2004) menemukan bahwa kualitas pelayanan perguruan tinggi ditentukan oleh 6 faktor, yaitu : tangibles, competence, attitude, content, delivery dan reliability. Hasil studi ini merupakan review dari peneliti sebelumnya Parasuraman et.al. (1985; 1988), Hill (1995)_ serta Kamal dan Ramzi (2002).

Sejumlah pakar mendefinisikan apa yang disebut dengan kepuasan pelanggan. Day (dalam Tse dan Wilton, 1988) mendefinisikan kepuasan atau ketidakpuasan pelanggan sebagai respon pelanggan terhadap evaluasi ketidaksesuaian (disconfirmation) yang dipersepsikan antara harapan awal sebelum pembelian dan kinerja aktual produk yang dirasakan setelah pemakaiannya. Sementara itu Kotler (2019) mendefinisikan kepuasan pelanggan adalah tingkat perasaan seseorang setelah membandingkan kinerja (hasil) yang ia rasakan dibandingkan dengan harapannya. Dari kedua definisi tersebut di atas, maka terdapat kesamaan, yaitu menyangkut komponen kepuasan pelanggan (harapan dan kinerja atau hasil yang dirasakan). Pada umumnya harapan pelanggan merupakan perkiraan atau keyakinan pelanggan tentang apa yang akan diterimanya bila ia membeli atau mengkonsumsi suatu produk. Sedangkan kinerja yang dirasakan adalah persepsi pelanggan terhadap apa yang ia terima setelah mengkonsumsi produk yang dibeli (Tjiptono, 1996).

Sedangkan menurut model indek kepuasan pelanggan Amerika, kepuasan pelanggan keseluruhan ditentukan oleh faktor nilai yang dirasakan, kualitas yang dirasakan dan harapan pelanggan. Kepuasan pelanggan keseluruhan mempunyai konsekuensi perilaku berupa komplain pelanggan dan kesetiaan pelanggan (Fornell, et.al., 1996).

Selain itu, Kelsey dan Bond (2001) mendefinisikan kepuasan pelanggan sebagai hasil yang dicapai ketika jasa atau barang yang dihasilkan dapat memenuhi kebutuhan dan harapan pelanggan untuk jangka waktu panjang. Dalam studinya Kelsey dan Bond (2001) menemukan beberapa penentu kepuasan pelanggan pada jasa pendidikan yang terdiri dari 32 item.

Mengacu pada beberapa definisi tentang kepuasan pelanggan yang telah dikemukakan oleh beberapa pakar, maka dapatlah dijelaskan bahwa kepuasan pelanggan merupakan salah satu faktor penting yang menentukan kesuksesan perusahaan di masa yang akan datang. Untuk mewujudkan dan membangun kepuasan pelanggan secara konsisten dibutuhkan investasi yang besar dan jangka waktu yang panjang, karena pada hakekatnya kepuasan pelanggan merupakan strategi jangka panjang dan manfaatnya dapat bertahan lama. Oleh karena itu kepuasan pelanggan perlu diikuti dengan customer delight dan loyalitas pelanggan. Hal 
ini berarti bahwa kepuasan pelanggan harus dapat diterjemahkan ke dalam volume penjualan yang lebih besar, aset yang lebih produktif dan Return on Investment yang lebih tinggi (Tjiptono, 2019).

Dalam dekade saat ini orientasi perusahaan berfokus pada loyalits pelanggan. Loyalitas pelanggan dapat dianalisis melalui dua pendekatan, yaitu pendekatan keperilakuan (behavioural approach) dan pendekatan kesikapan (attitudinal approach). Pendekatan keperilakuan menekankan pada runtutan pembelian, proporsi pembelian yang lebih bersifat operasional yang menggunakan berbagai ukuran perilaku yang diperoleh dari data panel. Pendekatan kesikapan menekankan pada komitmen psikologis terhadap obyek yang menggunakan ukuran melalui kepuasan, komitmen dan nita (Dick dan Basu, 1994 ; Dharmmesta, 1999).

Dharmmesta (1999) mengemukakan bahwa loyalitas dapat dipahami melalui beberapa tahap, yaitu : (1) loyalitas kognitif, pada tahap ini konsumen menggunakan basis informasi yang memaksa untuk menunjuk pada satu merek atas merek lainnya, (2) loyalitas afektif, pada tahap ini menekankan pada aspek afektif konsumen, (3) loyalitas konatif, pada tahap ini menekankan pada aspek konatif yang menunjukkan suatu niat atau komitmen untuk melakukan sesuatu dengan tujuan tertentu, (4) loyalitas tindakan, pada tahap ini aspek konatif atau niat sudah dikonversi menjadi tindakan atau perilaku.

Definisi loyalitas pelanggan dikemukakan oleh beberapa ahli. Mowen dan Minor (1998) dalam Dharmmesta (1999) mendefinisikan loyalitas pelanggan merupakan sikap positif konsumen terhadap suatu merek, mempunyai komitmen pada merek tersebut, dan bermaksud meneruskan pembeliannya di masa mendatang. Sedangkan menurut Sheth dan Mittal (2004) dalam Tjiptono (2019) mendefinisikan loyalitas pelanggan sebagai komitmen pelanggan terhadap suatu merek, toko, atau pemasok, berdasarkan sikap yang sangat positif dan tercermin dalam pembelian ulang yang konsisten.

Hasil studi Wei dan Ramalu (2011) membuktikan bahwa kualitas pelayanan berpengaruh terhadap kepuasan mahasiswa. Selain itu Kaura dan Datta (2012) membuktikan pengaruh kualitas pelayanan yang mencakup people, process dan physical evidence terhadap pelanggan. Hasil studi ini didukung oleh Kaura (2013) yang menunjukkan bahwa kualitas pelayanan menjadi anteseden kepuasan pelanggan. Demikian juga hasil studi Kaura et. al. (2015) membuktikan bahwa kualitas pelayanan berpengaruh terhadap kepuasan pelanggan dan loyalitas pelanggan. Hasil studi Asakdiyah (2018) menunjukkan bahwa kualitas pelayanan berpengaruh terhadap kepuasan mahasiswa dan loyalitas mahasiswa yg diukur melalui komunikasi word of mouth mahasiswa.

Model SERVQUAL (Service Quality) merupakan model populer dan sampai saat ini masih dipergunakan sebagai acuan dalam riset pemasaran. Model ini dikembangkan oleh tiga peneliti Amerika yaitu : Parasuraman, Zeithaml dan Berry (1985). Model SERVQUAL ini meliputi analisis terhadap lima gap yang berpengaruh terhadap kualitas jasa. Model tersebut berkaitan erat dengan model kepuasan pelanggan yang sebagian besar didasarkan pada pendekatan diskonfirmasi (Oliver, 1999). Model SERVQUAL ini menganalisis gap antara dua variabel pokok yaitu : jasa yang diharapkan dan jasa yang dipersepsikan. Jasa yang diharapkan merupakan harapan pelanggan sebelum membeli dan mengkonsumsikan suatu jasa sebagai standard atau acuan dalam mengevaluasi kinerja jasa yang bersangkutan. Sedangkan jasa yang dipersepsikan merupakan keyakinan konsumen mengenai jasa yang diterima atau jasa yang dialami (Brown dan Swartz, 1989).

Cronin dan Taylor (1992) mengartikan persepsi terhadap kualitas sebagai kinerja (performance). Cronin dan Taylor (1992) membuktikan bahwa kualitas jasa ditentukan oleh kinerja jasa tersebut. Menurut Cronin dan Taylor (1992) kinerja minus harapan bukan merupakan dasar yang cocok untuk mengukur kualitas jasa. Bahkan Carman (1990) mengungkapkan hasil penelitian yang berkaitan dengan persepsi dan harapan terhadap kualitas jasa, dan Carman menyimpulkan bahwa perbedaan persepsi dan harapan sulit untuk dianalisis, hal ini disebabkan responden harus memberikan persepsi dan harapan pada waktu bersamaan berdasarkan pengalaman masa lalu. Akan tetapi hasil penelitian ini disanggah oleh Parasuraman, Zeithaml dan Berry (1994), dan mereka masih tetap mempertahankan hasil penelitian mereka (1985).

Berdasarkan dua pendapat tersebut, maka pada penelitian ini menggunakan pendekatan yang digunakan oleh Cronin dan Taylor (1992). Selain itu Parasuraman, Zeithaml dan Berry $(1985 ; 1988)$ berpendapat pula bahwa semakin tinggi tingkat kualitas jasa yang dipersepsikan, maka semakin besar pula kepuasan konsumen. Hasil penelitian ini juga sesuai dengan hasil penelitian Cronin dan Taylor (1994) yang menyatakan bahwa kualitas jasa adalah anteseden bagi kepuasan konsumen.

Para ahli telah melakukan penelitian tentang loyalitas pelanggan yang digolongkan menjadi dua jenis loyalitas yaitu loyalitas kesikapan dan loyalitas keperilakuan (Pritckard et.al, 1999; Dharmmesta, 1999). Loyalitas pelanggan dapat dibangun melalui loyalitas kognitif (kualitas pelayanan), kualitas afektif (kepuasan pelanggan), dan loyalitas konatif dan akhirnya loyalitas tindakan (loyalitas yang ditopang dengan komitmen 
dan tindakan). Dengan demikian penguatan loyalitas pelanggan dapat di perkuat melalui berbagai upaya peningkatan kualitas pelaksanaan, kepuasan pelanggan dan komitmen pelanggan (Dharmmesta, 1999).

Mengingat arti pentingnya kualitas pelayanan bimbingan akademik dan kepuasan mahasiswa dalam rangka penguatan loyalitas mahasiswa, maka studi ini dilakukan untuk mengevaluasi kualitas pelayanan bimbingan akademik dan kepuasan mahasiswa dalam upaya tercapainya loyalitas mahasiswa pada Program Studi Manajemen Fakultas Ekonomi dan Bisnis Universitas Ahmad Dahlan Yogyakarta. Hasil evaluasi ini dapat digunakan sebagai dasar perbaikan kualitas pelayanan bimbingan akademik dan peningkatan kepuasan mahasiswa sehingga akan memperkuat loyalitas mahasiswa.

\section{Metode}

Populasi dalam penelitian ini adalah mahasiswa Program Studi Manajemen Fakultas Ekonomi dan Bisnis Universitas Ahmad Dahlan Yogyakarta. Sampel ditentukan dengan metode Convenience sampling dan metode purposive sampling. Convenience sampling merupakan suatu metode untuk memilih anggota populasi yang paling mudah untuk ditemui dan dimintai informasi (Hadi, 1987). Sedangkan purposive sampling merupakan metode pemilihan sampel berdasarkan pertimbangan tertentu (Cooper dan Emory, 1995; Babbie, 1995). Adapun kriterianya sebagai berikut : Responden dalam penelitian ini adalah mahasiswa Program Studi Manajemen Fakultas Ekonomi dan Bisnis terdaftar sebagai mahasiswa pada semester ganjil TA 2020/2021. Mahasiswa yang dijadikan sampel adalah mahasiswa yang sudah mendapatkan bimbingan dari Dosen Pembimbing akademik. Dalam penelitian ini jumlah sampel ditentukan minimal berjumlah 100 responden. Penentuan jumlah sampel ini didasarkan pada pendapat Roscoe dalam Sekaran (1992) yang menyatakan bahwa jumlah sampel lebih besar dari 30 dan kurang dari 500 responden pada sebagian penelitian sudah mewakili.

Kepuasan mahasiswa diukur dengan menggunakan empat dimensi, yang terdiri dari harga (price), pelayanan (services), citra (image) dan kepuasan pelanggan secara keseluruhan (overall customer satisfaction). Keempat dimensi ini dikembangkan berdasar pada Naumann dan Giel (1995) dan Madu, Kueh dan Jacob (1996), terdiri dari 7 item dan diukur dengan skala likert 7 point. Angka satu mewakili jawaban sangat tidak setuju dan angka tujuh mewakili jawaban sangat setuju. Loyalitas mahasiswa diukur dengan menggunakan instrumen yang dikembangkan berdasarkan Pritchard et.al. (1999) dan Taylor et.al (2004) yang terdiri dari 10 item. Masing-masing item diukur dengan skala 7 point.

Untuk mendapatkan data yang berkualitas, maka instrumen penelitian harus diuji validitas dan reliabilitasnya (Huck dan Cormier, 1996). Uji validitas dilakukan untuk mengukur apa yang ingin diukur (Ancok, 1989). Untuk menguji validitas instrumen penelitian ini digunakan Pearson Product Moment Test. Sedangkan uji reliabilitas dilakukan untuk mengetahui sejauhmana hasil suatu pengukuran dapat dipercaya (Azwar, 1997). Untuk menguji reliabilitas instrumen penelitian ini digunakan Cronbach Alpha.

Untuk menguji hipotesis yang dikemukakan, maka digunakan uji $\mathrm{t}$ dan uji $\mathrm{F}$. Uji $\mathrm{t}$ dimaksudkan untuk mengetahui variabel bebas (independen variabel) yang berpengaruh secara signifikan terhadap variabel terikat secara individual. Sedangkan uji $\mathrm{F}$ digunakan untuk mengetahui apakah secara bersama-sama variabelvariabel bebas tersebut dapat menjelaskan variabel terikat.

\section{Hasil dan Pembahasan}

\section{Uji Validitas dan Reliabilitas}

Uji Validitas dan Reliabilitas dilakukan untuk menghasilkan data yang berkualitas. Product Moment Test digunakan untuk menguji validitas instrumen penelitian ini. Sedangkan Cronbach Alpha digunakan untuk menguji reliabilitas instrumen penelitian agar hasil pengukuran dapat dipercaya.

Dalam penelitian ini menggunakan variabel kualitas pelayanan bimbingan akademik dan kepuasan mahasiswa sebagai variabel bebas. Kualitas pelayanan bimbingan akademik diukur dengan instrumen yang disusun oleh Jusoh et.al (2004) yang terdiri dari 12 item dan masing-masing item diukur dengan menggunakan skala 7 point. Kepuasan mahasiswa diukur menggunakan instrumen yang dikembangkan oleh Naumaun dan Giel (1995) serta Madu et.al (1996) yang terdiri dari 7 item dan diukur dengan menggunakan skala 7 point. Sedangkan variabel loyalitas mahasiswa merupakan variabel terikat. Loyalitas mahasiswa diukur dengan menggunakan instrumen yang disusun oleh Pritchard et.al (1999) dan Taylor et.al (2004). Variabel loyalitas mahasiswa terdiri dari 10 item dan masing-masing item diukur dengan menggunakan skala 7 point.

Hasil uji validitas variabel kualitas pelayanan bimbingan akademik, kepuasan mahasiswa dan loyalitas mahasiswa menunjukkan semua item-item yang digunakan dalam instrumen penelitian ini dinyatakan valid karena R hitung > R tabel. 
Hasil uji reliabilitas baik variabel kualitas pelayanan bimbingan akademik, kepuasan mahasiswa dan loyalitas mahasiswa menghasilkan nilai Alpha lebih besar dari 0,50. Hasil ini menunjukkan bahwa variabel kualitas pelayanan bimbingan akademik, kepuasan mahasiswa dan loyalitas mahasiswa dinyatakan reliabel (andal).

\section{Model Penguatan Loyalitas Mahasiswa}

Berdasarkan Moderator Regression Analysis (MRA) dari Taylor dan Baker (1994), maka model penguatan loyalitas mahasiswa dapat dianalisis melalui pengaruh variabel kualitas pelayanan bimbingan akademik, kepuasan mahasiswa dan interaksi antara kualitas pelayanan bimbingan akademik dengan kepuasan mahasiswa. Model penguatan loyalitas mahasiswa dapat dianalisis melalui tiga persamaan regresi dengan cara mencari $\mathrm{R}^{2}$ dari masing-masing persamaan. Nilai $\mathrm{R}^{2}$ yang dihasilkan dimaksudkan untuk mengetahui tipe efek moderator yang ada.

Model persamaan pertama menggunakan variabel kualitas pelayanan bimbingan akademik sebagai variabel bebas. Model persamaan kedua menggunakan variabel kualitas pelayanan bimbingan akademik dan kepuasan mahasiswa sebagai variabel bebas. Sedangkan model persamaan ketiga menggunakan variabel kualitas pelayanan bimbingan akademik, kepuasan mahasiswa serta interaksi antara kualitas pelayanan bimbingan akademik dengan kepuasan mahasiswa sebagai variabel bebas.

Dalam penelitian ini Moderator Regression Analysis (MRA) dapat dijelaskan melalui rumus sebagai berikut :

Dimana :

$$
\mathrm{Y}=\alpha+\beta_{1} \mathrm{X}+\beta_{2} \mathrm{Z}+\beta_{3} \mathrm{XZ}
$$

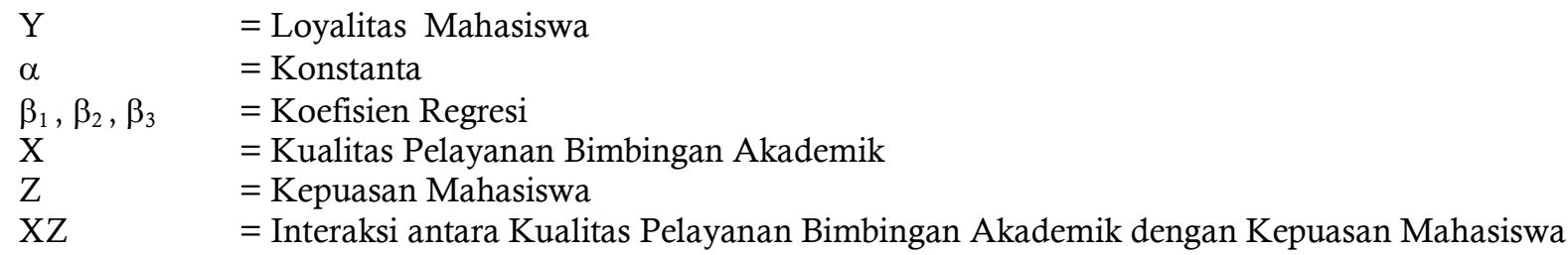

Berdasarkan analisis regresi dari 100 mahasiswa Program Studi Manajemen Fakultas Ekonomi dan Bisnis Universitas Ahmad Dahlan (FEB - UAD) dapat dijelaskan melalui tabel sebagai berikut :

Tabel 1. Hasil Analisis Regresi

\begin{tabular}{llllllll}
\hline Model & Variabel & $\alpha$ & $\beta$ & Nilai t & Prob & $\mathbf{R}^{2}$ & Nilai F \\
\hline $\mathbf{1}$ & $\begin{array}{l}\text { Kualitas Pelayanan } \\
(\mathrm{X})\end{array}$ & 1,222 & 0,720 & 11,568 & 0,000 & 0,577 & 133,821 \\
$\mathbf{2}$ & $\begin{array}{l}\text { Kualitas Pelayanan } \\
(\mathrm{X})\end{array}$ & 0,323 & 0,349 & 6,075 & 0,000 & 0,792 & 184,667 \\
& $\begin{array}{l}\text { Kepuasan } \\
\text { Mahasiswa (Z) }\end{array}$ & & 0,590 & 10,007 & 0,000 & & \\
$\mathbf{3}$ & $\begin{array}{l}\text { Kualitas Pelayanan } \\
(\mathrm{X})\end{array}$ & 0,867 & 0,194 & 2,099 & 0,038 & 0,801 & 129,077 \\
& $\begin{array}{l}\text { Kepuasan } \\
\text { Mahasiswa (Z) }\end{array}$ & 0,438 & 4,781 & 0,000 & & \\
& Interaksi (XZ) & 0,041 & 2,125 & 0,036 & & \\
\hline
\end{tabular}

Sumber : Data Primer, diolah

Berdasarkan tabel tersebut diatas, maka dapat dijelaskan sebagai berikut:

\section{Persamaan Model 1 (Pertama)}

Persamaan model pertama menghasilkan besarnya konstanta (intersep) sebesar 1,222 dan koefisien regresi sebesar 0,720 . Hasil ini dapat dirumuskan sebagai berikut :

$$
\mathrm{Y}=1,222+0,720 \mathrm{X}
$$

Persamaan model pertama menunjukkan bahwa apabila kualitas pelayanan bimbingan akademik sama dengan nol, maka besarnya loyalitas mahasiswa sebesar 1,222 . Sedangkan kenaikan variabel kualitas pelayanan bimbingan akademik sama dengan 1 , maka loyalitas mahasiswa akan mengalami kenaikan sebesar 0,720 .

Hasil uji t dengan $\alpha=5 \%$ menunjukkan nilai t hitung sebesar 11,568 dengan probabilitas sebesr $0,000<$ 0,05 . Hasil uji $\mathrm{t}$ ini menunjukkan bahwa kualitas pelayanan bimbingan akademik berpengaruh signifikan terhadap loyalitas mahasiswa. Hasil uji $\mathrm{F}$ dengan $\alpha=5 \%$ menghasilkan nilai $\mathrm{F}$ sebesar 133,821 dengan 
probabilitas sebesar $0,000<0,05$. Hal ini menunjukkan bahwa kualitas pelayanan bimbingan akademik berpengaruh signifikan terhadap loyalitas mahasiswa. Sedangkan nilai $\mathrm{R}^{2}$ sebesar 0,577 menunjukkan bahwa variance loyalitas mahasiswa dijelaskan oleh variance kualitas pelayanan bimbingan akademik sebesar $57,7 \%$. Sisanya sebesar 42,3\% dapat dijelaskan oleh variabel lain yang tidak dimasukkan dalam model penelitian.

\section{Persamaan Model 2 (kedua)}

Persamaan model kedua dapat dirumuskan sebagai berikut :

$$
\mathrm{Y}=0,323+0,349 \mathrm{X}+0,590 \mathrm{Z}
$$

Persamaan model kedua menunjukkan konstanta sebesar 0,323. Konstanta sebesar 0,323 berarti rata-rata loyalitas mahasiswa akan mengalami kenaikan sebesar 0,323 apabila variabel kualitas pelayanan bimbingan akademik dan kepuasan mahasiswa sama dengan nol. Koefisien regresi kualitas pelayanan bimbingan akademik $\left(\beta_{1}\right)$ sebesar 0,349 . Angka ini menunjukkan bahwa apabila kualitas pelayanan bimbingan akademik naik sebesar 1 ceteris paribus akan meningkatkan loyalitas mahasiswa sebesar 0,349. Koefisien regresi kepuasan mahasiswa $\left(\beta_{2}\right)$ sebesar 0,590 menunjukkan apabila kepuasan mahasiswa naik sebesar 1 ceteris paribus akan meningkatkan loyalitas mahasiswa sebesar 0,590 .

Uji $t$ yang menghasilkan $t$ hitung variabel kualitas pelayanan bimbingan akademik sebesar 6,075 menunjukkan bahwa variabel kualitas pelayanan bimbingan akademik berpengaruh signifikan terhadap loyalitas mahasiswa dengan probabilitas sebesar $0,000<0,05$. Hasil uji t pengaruh kepuasan mahasiswa terhadap loyalitas mahasiswa sebesar 10,007 dengan probabilitas sebesar 0,000< 0,05 . Angka ini menunjukkan bahwa kepuasan mahasiswa berpengaruh signifikan terhadap loyalitas mahasiswa.

Uji $\mathrm{F}$ dengan $\mathrm{F}$ hitung sebesar 184,667 menunjukkan bahwa variabel kualitas pelayanan bimbingan akademik dan kepuasan mahasiswa secara bersama-sama berpengaruh terhadap loyalitas mahasiswa.

Nilai $\mathrm{R}^{2}$ sebesar 0,792 menunjukkan bahwa variance loyalitas mahasiswa dijelaskan oleh variance kualitas pelayanan bimbingan akademik dan kepuasan mahasiswa sebesar 79,2\%. Sedangkan sisanya sebesar 20,8\% dapat dijelaskan oleh variabel lain yang tidak dimasukkan dalam model penelitian.

Persamaan Model 3 (ketiga)

Persamaan model ketiga dapat dirumuskan sebagai berikut :

$$
\mathrm{Y}=0,867+0,194 \mathrm{X}+0,438 \mathrm{Z}+0,041 \mathrm{XZ}
$$

Persamaan model ketiga memasukkan kualitas pelayanan bimbingan akademik, kepuasan mahasiswa dan interaksi antara kualitas pelayanan bimbingan akademik dengan kepuasan mahasiswa sebagai variabel bebas. Konstanta sebesar 0,867 menunjukkan bahwa apabila variabel kualitas pelayanan bimbingan akademik, kepuasan mahasiswa, serta interaksi antara kualitas pelayanan bimbingan akademik dengan kepuasan mahasiswa sama dengan nol, maka loyalitas mahasiswa sebesar 0,867.

Koefisien regresi kualitas pelayanan bimbingan akademik sebesar 0,194. Hal ini menunjukkan bahwa apabila kualitas pelayanan bimbiangan akademik naik sebesar 1 ceteris paribus, maka akan meningkatkan loyalitas mahasiswa sebesar 0,194. Koefisien regresi kepuasan mahasiswa sebesar 0,438. Hal ini menunjukkan bahwa apabila kepuasan mahasiswa naik sebesar 1 ceteris paribus, maka akan meningkatkan loyalitas mahasiswa sebesar 0,438. Koefisien regresi interaksi antara kualitas pelayanan bimbingan akademik dengan kepuasan mahasiswa sebesar 0,041. Hal ini menunjukkan bahwa apabila interaksi antara kualitas pelayanan bimbingan akademik dengan kepuasan mahasiswa naik sebesar 1 ceteris paribus, maka akan meningkatkan loyalitas mahasiswa sebesar 0,041.

Hasil uji t pengaruh kualitas pelayanan bimbingan akademik dengan loyalitas mahasiswa dengan t hitung sebesar 2,099 dan probabilitas sebesar 0,038<0,05. Hal ini menunjukkan bahwa secara parsial kualitas pelayanan bimbingan akademik berpengaruh secara signifikan terhadap loyalitas mahasiswa.

Hasil uji t pengaruh kepuasan mahasiswa terhadap loyalitas mahasiswa dengan t hitung sebesar 4,781 dan probabilitas sebesar $0,000<0,05$. Hal ini menunjukkan bahwa secara parsial kepuasan mahasiswa berpengaruh secara signifikan terhadap loyalitas mahasiswa. Hasil uji t pengaruh interaksi kualitas pel Universitas Ahmad Dahlan ayanan bimbingan akademik dengan loyalitas mahasiswa dengan $\mathrm{t}$ hitung sebesar 2,125 dan probabilitas sebesar $0,036<0,05$. Hal ini menunjukkan bahwa secara parsial interaksi kualitas pelayanan bimbingan akademik dengan kepuasan mahasiswa berpengaruh signifikan terhadap loyalitas mahasiswa.

Hasil uji F menunjukkan F hitung sebesar 129,077 dengan probabilitas sebesar 0,000. Hal ini, menunjukkan bahwa kualitas pelayanan bimbingan akademik, kepuasan mahasiswa, serta interaksi antara kualitas 
pelayanan bimbingan akademik dengan kepuasan mahasiswa secara bersama-sama berpengaruh terhadap loyalitas mahasiswa.

Nilai $\mathrm{R}^{2}$ sebesar 0,801 menunjukkan bahwa variance loyalitas mahasiswa dapat dijelaskan oleh variance kualitas pelayanan bimbingan akademik, kepuasan mahasiswa, serta interaksi antara kualitas pelayanan bimbingan akademik dengan kepuasan mahasiswa sebesar 80,1\%. Sedangkan sisanya sebesar 19,9\% dapat dijelaskan oleh variabel lain yang tidak dimasukkan dalam penelitian.

Hasil analisis data dengan menggunakan MRA menunjukkan bahwa variabel kepuasan mahasiswa sebagai variabel moderator yang mempunyai pengaruh yang signifikan terhadap pengaruh kualitas pelayanan bimbingan akademik dengan loyalitas mahasiswa. Hal ini dapat ditunjukkan dengan nilai $\mathrm{R}^{2}$ yang dihasilkan dari ketiga persamaan model yang ada mengalami peningkatan nilai.

Pada persamaan model pertama menunjukkan nilai $\mathrm{R}^{2}$ sebesar 0,577 . Nilai $\mathrm{R}^{2}$ pada persamaan model kedua menunjukkan nilai $R^{2}$ sebesar 0,792 . Nilai $R^{2}$ pada persamaan model ketiga menunjukkan nilai $R^{2}$ sebesar 0,801 . Nilai $\mathrm{R}^{2}$ pada persamaan model ketiga lebih tinggi dari nilai $\mathrm{R}^{2}$ persamaan model kedua. Demikian pula nilai $\mathrm{R}^{2}$ persamaan model kedua, persamaan model kedua nilai $\mathrm{R}^{2}$ lebih tinggi dari nilai $\mathrm{R}^{2}$ persamaan model pertama.

Dengan demikian hasil penelitian ini memperkuat model MRA yang disusun oleh Taylor dan Baker (1994). Hal ini dapat ditunjukkan melalui persamaan model ketiga ketika menggunakan variabel kualitas pelayanan, kepuasan mahasiswa, serta interaksi antara kualitas pelayanan dengan kepuasan mahasiswa sebagai varaibel bebas dengan nilai $\mathrm{R}^{2}$ yang paling tinggi.

\section{Simpulan}

Adapun kesimpulan dari penelitian ini adalah Hasil penelitian menunjukkan bahwa kualitas pelayanan bimbingan akademik berpengaruh signifikan terhadap loyalitas mahasiswa. Hasil penelitian menunjukkan bahwa kepuasan mahasiswa mempunyai pengaruh yang signifikan terhadap loyalitas mahasiswa. Hasil penelitian menunjukkan bahwa interaksi antara kualitas pelayanan bimbingan akademik dengan kepuasan mahasiswa lebih menjelaskan variance loyalitas mahasiswa daripada masing-masing variabel. 4) Hasil penelitian menunjukkan bahwa kepuasan mahasiswa sebagai variabel moderator mempunyai efek yang signifikan dari pada pengaruh kualitas pelayanan bimbingan akademik terhadap loyalitas mahasiswa. 5) Variabel loyalitas mahasiswa mampu dijelaskan oleh kualitas pelayanan bimbingan akademik, kepuasan mahasiswa, serta interaksi antara kualitas pelayanan bimbingan akademik dengan kepuasan mahasiswa sebesar $80,1 \%$. Sedangkan sisanya sebesar 19,9\% dapat dijelaskan oleh variabel lain yang tidak dimasukkan dalam penelitian ini. Dalam penelitian yang akan datang hendaknya perlu digali variabel moderator yang lain misalnya variabel trust mahasiswa yang mempunyai peran penting dalam membangun loyalitas mahasiswa. Hasil studi Seto (2012) menunjukkan bahwa variabel trust mempunyai peran penting dalam membentuk loyalitas pelanggan.

\section{Referensi}

Ancok, D. (1989), "Validitas dan Reliabilitas Instrumen Penelitian," M. Singarimbun dan S. Effendi (ed.), Metodologi Penelitian, Survai, Yogyakarta : LP3ES.

Asakdiyah, S.(2018), Membangun Komunikasi Word of Mouth Melalui Anteseden dan Konsekuensi Kualitas Pelayanan Perguruan Tinggi, Disertasi, Yogyakarta: Program Doktor Ilmu Ekonomi UII.

Arcaro, J.S. (1995), Quality in Education, Delray Beach : St. Lucie Press.

Azwar, S. (1997), Reliabilitas dan Validitas, Yogyakarta : Pustaka Pelajar.

Babbie, E. (1995), The Practice of Social Research, 7th ed., Belmaut : Wadsworth Publishing Company.

Brown, S.W. dan T.A. Swartz (1989), "A Gap Analysis of Professional Service Quality," Journal of Marketing, Vol. 53, April, p. 92-98.

Cooper, D.R. dan C.W. Emory (1995), Business Research Methods, 5th ed., Chicago : Richard D. Irwin Inc.

Cronin, J.J. dan S.A. Taylor (1992), "Measuring Service Quality : A Re examination and Extension," Journal of Marketing, July, p. 55-68.

Dharmmesta, B.S. (1999), "Loyalitas Pelanggan: sebuah Kajian Konseptual sebagai Panduan Bagi Peneliti," Jurnal Ekonomi dan Bisnis Indonesia, Vol. 14, No. 3, p. 73-88.

Dick, A.S. and K. Basu (1994), "Customer Loyalty : Toward and Integrated Conseptual Frame work," Journal of The Academy of Marketing Science, Vol. 22, No. 2 (Spring), p. 99-113.

Fitzsimmons, J.A. dan M.J. Fitzimmonz (1994), Service Management For Competitive Advantage, New York : Mc. Graw - Hill Inc. 
Fornell, C.J.D., Michael, A.W. Eugene, C. Jaesung and B.E. Barbara (1996), "The American Customer Satisfaction Index : Nature, Purpose and Finding." Journal of Marketing, Vol. 60, October, p. 7-8.

Hadi, S. (1987), Metodologi Research, Jilid I, Yogyakarta : Yayasan Penerbit Fakultas Psikologi UGM.

Hill, F.M (1995), "Managing Service Quality in Higher Education : The Role of The Student as Primary Consumer," Quality Assurance in Education, Vol. 3, No.3, p. 10-21.

Huck, S.W. dan Cormier, W.H. (1996), Reading Statistics and Research, 2nd ed., New York : harper Collins Publishers Inc.

Joseph, M., M. Yakhou dan G. Stone (2005), “An Educational Institution's Quest for Service Quality : Customers' Perspective, "Quality Assurance In Education", Vol. 13, No. 1, p. 66 - 82.

Jusoh, M.,S.Z. Omain, N.A. Majid, H.Md. Son. and A.S. Shamsuddin (2004), "Service Quality in Higher Education : Management Student's Perspective," Research Management Centre, University of Technology Malaysia.

Kamal, A. and N. Ramzi (2002), 'Assuring Quality Service in Higher Education : Registration and Advising Attitudes in A Private University in Lebanon," Quality Assurance in Educational, Vol. 10, No. 4, p. 198206.

Kaura, V. dan S.K. Datta(2012), "Impact of Service Quality on Satisfaction in The Indian Banking Sector," The IUP Journal of Marketing Management, Vol. II, No. 3, p.38-47.

Kaura, V.(2013), "Antecedent of Customer Satisfaction: A Study of Indian Public and Private Sector Bank, " International Journal of Bank Marketing, Vol. 31, No. 3, p.167-186.

Kaura, V., S.D. Prasad dan S. Sharma(2015), " Service Quality, Service Convenience, Price and Fairness, Customer Loyalty and The Mediating Role of Customer Satisfaction, " International Journal of Bank Marketing, Vol.33, No.4, p.404-422.

Kelsey, K.D. dan J.A. Bond (2001), "A Model for Measuring Customer Satisfaction Within an Academic Center of Excellence, "Managing Service Quality", Vol. 11, No. 5, p.359 - 367.

Kotler, P. (1997), Marketing Management : Analysis, Planning, Implementation and Control, 9th ed. Upper Saddle River, New Jersey : Prentice Hall Inc.

Madu, N.C., C.H. Kuch dan Jacob (1996), "An Empirical Assesment of The Influence o Quality Dimensions On Organizational Performance, "International Production Research, Vol. 34, No. 7, p. 1943-1962.

Mantra, IB. dan Kasto (1989), "Penentuan Sampel," M. Singarimbun dan S. Effendi (ed.), Metode Penelitian Survai, Yogyakarta : LP3ES.

Nasir, M.(2016), " Menghadapi Masyarakat Ekonomi ASEAN, Perguruan Tinggi Indonesia Harus Memiliki Daya Saing, " Berita Dirjen Belmawa, 25 Juli, http ://www.belmawa.ristekdikti.go.id. Diakses 24 November 2016.

Naumann, E. dan K. Giel (1995), Customer Satisfaction Measurement and Management, Cincinnati, Ohio : Thomson Executive Press.

Oliver, R.L. (1999), "Whence Consumer Loyalty," Journal of Marketing, Vol. 63 (Special Issue), p. 33-44.

Parasuraman, A, V.A. Zeithaml, dan L.L. Berry (1985), "A Conceptual Model of Service Quality and Implication for Future Research, "Journal of Marketing, Vol. 49, p.41-50.

Parasuraman, A, V.A. Zeithaml, dan L.L. Berry (1988), "SERVQUAL : A Multiple - Item Scale For Measuring Consumer Perceptions of Service Quality," Journal of Retailing, 64 (1), p. 12-14.

Pritchard, M.P., M.E. Havitz, D.R. Howard (1999), "Analyzing the Commitment Loyalty Link In Service Contexts," Journal of The Academy of Marketing Science, Vol. 27, No. 3, p. 333 - 348.

Sekaran, U. (1992), Research Methods for Business : A Skill - Building Approach, 2nd ed., New York : John Wiley \& Sons Inc.

Taylor, A.S. dan Baker, L.T. (1994), "An Assessment of Relationship Between Service Quality and Customer Satisfaction in The Formation of Consumers' Purchase Intention," Journal of Retailing, Vol. 70, No. 2, p. 163-178. 